\title{
KEBHINEKAAN DAN PERSATUAN PERSPEKTIF TAFSIR NUSANTARA
}

\author{
Fitri Dewi Oktavia \\ Institut Dirosat Islamiyah Al-Amien (IDIA) Prenduan \\ fitridewi06590@gmail.com, \\ Moh. Jufriyadi Sholeh \\ Insitut Dirosat Islamiyah Al-Amien (IDIA) Prenduan \\ mohjufriyadisholeh@gmail.com
}

\begin{abstract}
The diversity of race, ethnicity, language, religion or culture is the sunnahtullah which must be used as a reference for mutual understanding, complement and embrace each other, so that there is unity not a split which neither party wanted. Unity can create a strong and unbreakable nation. This research will examine in depth the diversity and unity with the perspective of the Interpretation archipelago. In this research used a qualitative approach with the type of literature review namely by using a thematic method which is descriptive-comparative. This research is in the book of interpretation of the archipelago shows that all the diversity of languages, races, skin colors, religions, cultures and so on, influenced by the place where he lives, and the degree of every human being is the same what sets it apart is the quality of piety. While unity is described with the brotherhood of believers which is based on faith and
\end{abstract}


heredity, strife will end in chaos, while peace with the aim of seeking divine pleasure will be blessed.

Keywords : Diversity, culture and unity

\section{ABSTRAK}

Kebhinekaan ras, suku, bahasa, agama at aupun budaya merupakan sunnahtullah yang harus dijadikan acuan untuk saling memahami, melengkapi dan merangkul satu sama lain, sehingga terwujud persatuan bukan perpecahan yang tidak diinginkan oleh semua pihak. Persatuan dapat mewujudkan bangsa yang kuat dan tidak pecah. Penelitian ini akan mengkaji secara mendalam tentang kebhinekaan dan persatuan dengan perspektif Tafsir Nusantara. Dalam penelitian ini digunakan pendekatan kualitatif dengan jenis kajian pustaka yaitu dengan menggunakan metode tematik yang bersifat deskriptif-komparatif. Penelitian ini dalam kitab Tafsir Nusantara menunjukkan bahwa semua kebhinekaan bahasa, ras, warna kulit, agama, budaya dan lain sebagainya, dipengaruhi oleh tempat dimana ia tinggal, dan derajat setiap manusia adalah sama yang membedakannya adalah kualitas takwa. Sedangakan persatuan digambarkan dengan persaudaraan orang beriman yang didasarkan pada keimanan dan keturunan, perselisihan akan berakhir pada kekacauan sedangkan perdamaian dengan tujuan mencari ridho Ilahi akan mendapat rahmat. 
Fitri Dewi dan Moh Jufriyadi, Kebhinekaan dan Persatuan Perspektif Tafsir Nusantara

Kata Kunci: Kebhinekaan, Budayaa, Persatuan.

\section{A. PENDAHULUAN}

Istilah pluralisme secara harfiah dapat diartikan dengan beragam, jamak dan beberapa. Sesuatu akan dikatakan plural jika terdiri dari banyak jenis, berbagai sudut pandang ataupun latar belakang. ${ }^{1}$ Multikulturalisme diartikan dengan keragaman budaya dan secara umum mengarah pada keragaman yang berbasis agama, ras, etnis, bahasa ataupun budaya. ${ }^{2}$ Namun dalam buku Fikih Kebhinekaan dijelaskan bahwa istilah multikulturalisme secara umum digunakan untuk menjelaskan persoalan yang erat dengan sosial budaya, sedangkan istilah pluralisme digunakan untuk menjelaskan persoalan yang berkaitan dengan konteks keagamaan. ${ }^{3}$

Sedangkan persatuan merupakan suatu konsep yang mengandung kebaikan yang harus diterapkan oleh setiap generasi. Sehingga persatuan tidak hanya dilafalkan namun juga

${ }^{1}$ Maqbul Arib, "Dakwah di Tengah Keragaman dan Perbedaan Umat Islam,” Jurnal Dakwah Tabligh Vol.15, No. 1 (Juni) 2014, h. 37.

2 Masthuriyah Sa'dan, "Toleransi : Media Komunikasi Umat Beragama," Lembaga Penelitian dan Pengabdian Kepada Masyarakat Vol. 7, No. 2 (Juni-Desember) 2015, h. 92.

${ }^{3}$ Ahmad Syafii Maarif, dkk, Fikih Kebinekaan Cet. I (Jakarta: Mizan, 2015), 175. 
mengetahui hakikat dari nilai persatuan tersebut. ${ }^{4}$ Inti dari makna persatuan sendiri yaitu menyatu tidak terpecah belah. Karena kesatuan dapat dicirikan dengan adanya kesamaan. Jika ingin membangun persatuan ditengah kebhinekaan diperlukan kesadaran dan kemampuan melihat adanya kesamaan serta adanya kemampuan untuk melihat adanya persamaan, meskipun di sisi lain ada perbedaan..$^{5}$

Seiring dengan berkembangnya zaman pemikiran manusia semakin berkembang mengikuti alur zaman begitu juga dengan kebhinekaan yang sudah ada sejak dulu dengan tanpa persoalan, kini muncul stigma baru yang mengatakan anti-kebhinekaan dan mengaku sebagai umat Muslim. ${ }^{6}$ Dengan adanya stigma tersebut telah mencoreng nama baik agama Islam, sejauh ini agama Islam disebarkan tanpa kekerasan dan paksaan.

Tidak dapat diingkari bahwa kemajemukan yang dimiliki oleh masyarakat Indonesia dapat memberikan daya tarik tersendiri

${ }^{4}$ Syafii Maarif. dkk, 175.

${ }^{5}$ I Nyoman Pursika, "Kajian Analitik Terhadap Semboyan 'Bhineka Tunggal Ika," Jurnal Pendidikan dan Pengajaran Jilid 42, Nomor 1, (April) 2009, h.18.

${ }^{6}$ Choirul Anwar, "Islam dan Kebhinekaaan di Indonesia : Peran Agama dalam Merawat Perbedaan," Jurnal Pemikiran Islam 'Zawiyah Vol 4, No. 2 (Desember) 2018, h. 3. 
Fitri Dewi dan Moh Jufriyadi, Kebhinekaan dan Persatuan Perspektif Tafsir Nusantara

namun juga dapat mengantarkan pada hal negatif. Terlebih lagi dalam bidang keagamaan, seperti yang telah diketahui bahwa setiap keagamaan memiliki doktrin yang berbeda dengan agama lain. Jika menyinggung agama lain dapat dikatakan penistaan agama, padahal pada hakikatnya tidak ada niatan demikian. ${ }^{7}$

Contoh konflik yang masih berkaitan dengan kebhinekaan yaitu kejadian di Sumatra Utara pada tanggal 29 Juli 2016, tentang aksi pembakaran Vihara Juanda dan Klenteng di Tanjungbalai, keributan yang disebabkan kumandangkan adzan di sebuah masjid dimana salah satu warga dekat masjid merasa terganggu dengan kumandangan adzan dan terjadilah konflik. Seperti yang telah diketahui bahwa keagamaan merupakan hal yang sangat sensitif. ${ }^{8}$

Padahal konflik tersebut tidak lain hanya bermula dari kata tidak terima dan merasa terganggu, permasalahan tersebut dapat diselesaikan dengan musyawarah tanpa melibatkan kekerasan dalam kehidupan. Karena hidup di Indonesia penuh dengan kebhinekaan baik dari aspek suku, bangsa, bahasa dan lain

\footnotetext{
${ }^{7}$ Anwar, 2.
}

${ }^{8}$ Yuliyanto Budi Setiawan, "Kontestasi Isu Kebhinekaan dalam Media Sosial," preprint (INA-Rxiv, 3 Januari 2018), 3, diaksess padaa website. https://doi.org/10.31227/osf.io/am2hk. 
sebagainya. Dari berbagai aspek keragaman yang dimiliki oleh Negara Indonesia dapat dijadikan bahan untuk memajukan Negara, bukan untuk memecah belah Negara dengan permasalahan yang pada hakikatnya tidak perlu didebatkan. Agama Islam selalu menerima perbedaan pendapat dan pemikiran sejak zaman Rasulullah Saw dan para sahabat.

Namun mereka menyikapi perbedaan sebagai rahmat bukan sesuatu hal yang salah dan harus saling menyalahkan. Rasulullah Saw telah mengajarkan kepada ummatnya untuk melakukan musyawarah ketika terjadi perselisihan dan tidak mengajarkan untuk asal mengambil keputusan dalam kepentingan orang banyak.

Dari paparan di atas, penulis ingin mengetahui secara mendalam tentang hakikat kebhinekaan dan persatuan dengan perspektif Tafsir Nusantara, sehingga bukan hanya mengenal kata kebhinekaan dan persatuan. Namun dapat menyikapi keberagaman yang ada agar bersatu yaitu dengan berbagai kelebihan dan kekurangan yang telah Allah titipkan.

Metode Penelitian

Pendekatan yang digunakan yaitu pendekatan kualitatif, yang bertujuan untuk mengetahui secara mendalam mengenai 
Fitri Dewi dan Moh Jufriyadi, Kebhinekaan dan Persatuan Perspektif Tafsir Nusantara

informasi kebhinekaan dan persatuan. ${ }^{9}$ Dengan jenis penelitian kajian pustaka (Library reseacrh). Dengan demikian, data-data yang dibutuhkan merupakan data-data kepustakaan yang masih relevan yaitu berupa jurnal, buku dan kitab. Dengan menggunakan metode tematik yaitu peneliti memilih ayat al-Qur'an yang berhubungan dengan topik penelitian. ${ }^{10}$

Penelitian ini bersifat deskriptif (menggambarkan), dengan jenis penelitian komparatif, penelitian ini berusaha untuk memberikan gambaran tentang kebhinekaan dan persatuan kemudian menganalisanya. komparatif yaitu metode penelitian dengan cara membandingkan isi buku dengan buku lain namun masih dalam konteks yang sama. ${ }^{11}$

Sumber data dalam penelitian ini yaitu pertama, Sumber data primer merupakan sumber data utama atau pokok dalam penelitian ini yaitu kitab tafsir Hamka dan kitab tafsir M. Quraish

${ }^{9}$ Sugiono, Metode Penelitian Kombinasi (Mixed Methods) (Bandung: Alfabeta, 2017), 13.

${ }^{10}$ Susi Sumisih, "Konsep Bhineka tunggal Ika dalam Perspektif Tafsir al-Azhar dan Kontribusinya Bagi Negara Kesatuan Republik Indonesia" (Lampung : Universitas Islam Negeri Raden Intan, 2019).

11 Jumiati Mahmudi, "Implementasi Ta'aruf dalam Surat Al-Hujurat Ayat 13 Persepektif Mufassir Klasik dan Modern (Studi Komparatif Tafsir Al-Qurtubi dan Tafsir Al-Munir)" (Prenduan, Institut Dirosat Islamiyah Al-Amien (IDIA), 2018), h. 16. 
Shihab. Kedua, sumber data sekunder yaitu sumber data pelengkap seperti: buku-buku, jurnal-jurnal atau kitab-kitab yang sesuai dengan pembahasan penelitian.

Langkah yang dilakukan untuk mengumpulkan data yaitu: pertama, tinjauan terhadap data primer serta membatasi ayat alQur'an yang akan diteliti yaitu pada surat al-Hujurāt ayat 10 dan 13, surat ar-Rūm ayat 22 kemudian membatasi pada kitab tafsir yang akan diteliti. Kedua, mendekumentasikan data yang telah ada.

Langkah yang dilakukan untuk menganalisa data yaitu: Pertama, metode interpretasi yaitu menyingkap dan menyelami maksud dari karya tokoh tersebut. Kedua, metode deskriptif yaitu memberikan gambaran. Ketiga, metode komperasi yaitu membandingkan pemikiran dari tokoh mufassir yang telah peneliti tentukan. ${ }^{12}$

\footnotetext{
${ }^{12}$ Mahmudi, h. 17-18.
} 
Fitri Dewi dan Moh Jufriyadi, Kebhinekaan dan Persatuan Perspektif Tafsir Nusantara

B. PEMBAHASAN TENTANG KEBHINEKAAN SUKU ATAU RAS

Keragaman yang dimiliki Negara Indonesia menunjukkan warga yang kaya keberagaman dan jika dikelola dengan baik akan menjadi kekuatan dan keunikan. Tetapi sebaliknya jika tidak dapat menyikapinya dengan bijak dapat menimbulkan perpecahan.

Konsep keberagaman bukanlah hal yang baru dalam dunia Islam. Karena Islam memiliki pengalaman sejarah bahwa Islam sangat menghargai adanya keberagaman, sebagaimana telah diterapkan di masa Rasulullah. ${ }^{13}$ Dengan demikian kebhinekaan sangat relevan dengan ajaran agama Islam sebagaimana firmanNya

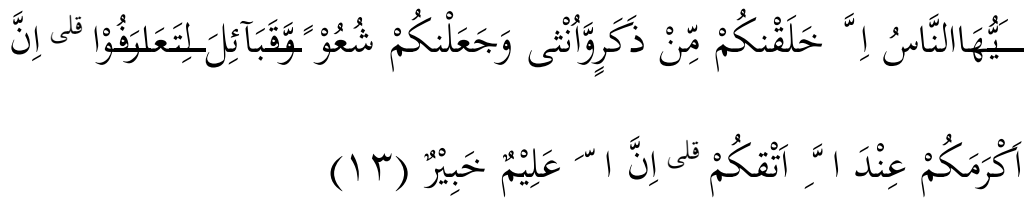

${ }^{13}$ Mubaidillah, "Tafsir Al-Lubab Karya M. Quraish Shihab (Kajian Metodologi Tafsir Kontemporer)," Nur El-Islam, Vol.3. No, 1 (April) 2016, h. 48. 
“Wahai manusia! Sungguh, kami telah menciptakan kamu dari seorang laki-laki dan seorang perempuan, kemudian kami jadikan kamu berbangsa-bangsa dan bersuku-suku agar kamu saling mengenal. Sungguh, yang paling mulia di antara kamu di sisi Allah ialah orang yang paling bertakwa. Sungguh, Allah Maha Mengetahui, Mahatelití'.(QS. Al-Hujurāt : 13) $)^{14}$

Sebab turunnya ayat yaitu yang diriwayatkan Abū Daud berkenaan dengan Abū Hind yang bekerja sebagai pembekam setiap hari. Nabi meminta kepada Banī Bayadhah untuk menikahkan putrinya dengan Abū Hind, namun mereka menolak karena ia pernah menjadi budak mereka. Sehingga sikap demikian di kecam oleh al-Qur'an dan ditegaskan bahwa kemuliaan bukan karena garis keturunan akan tetapi karena takwa.

Ayat tersebut menunjukkan asal usul manusia yang sama dan kesamaan derajat manusia. Maka tidak wajar jika seseorang merasa dirinya lebih dari orang lain. Allah telah menciptakan manusia dari hasil persetubuhan antara laki-laki dan perempuan. Hal tersebut untuk menegaskan bahwa derajat semua manusia sama. dan antara satu bangsa dengan yang lain tidak ada

${ }^{14}$ Indra Laksana, Syamsu Arramly, dan Abdul Raup, Yasmina al-Qur'an Terjemahan dan Tajwid, 1 ed. (Bandung: PT Sygma Examedia Arkanleema, 2014), h. 517. 
Fitri Dewi dan Moh Jufriyadi, Kebhinekaan dan Persatuan Perspektif Tafsir Nusantara

perbedaan. Orang yang mulia di sisi Allah yaitu orang yang bertakwa.

Kata (شعوب) yaitu jamak dari (شعب) biasanya digunakan untuk menunjukan sekian kumpulan (قيلة) yang diartikan "Suku yang berasal dari satu kakek”. Suku terbangun dari banyak kelompok keluarga yang dinamakan (عمارة) 'imārah yang terbangun dari banyak kelompok yang dinamakan (بطن) bathan dan dibawahnya terdapat (فخ) fakhadz sehingga sampai pada himpunan keluarga yang terkecil.

Kata (تعارفو) dari kata (عرف) yang berarti “mengenal”. Allah menjadikan manusia berbangsa, bersuku dan berkelompok untuk saling mengenal. Keengganan untuk saling mengenal merupakan salah satu dampak dari ketidak butuhannya yang menimbulkan kerusakan dunia. ${ }^{15}$

Manusia berasal dari percampuran laki-laki dengan perempuan yang menimbulkan perkumpulan dua mani, selama 41 hari lamanya dinamakan nuthfah. jadi darah kemudian menjadi

15 M. Quraish Shihab, Tafsir al-Mishbāh Pesan, Kesan dan Keserasian al-Qur'an, Jilid 13 (Jakarta: Lentera Hati, 2002), h. 260-264. 
daging ( 'alaqah). Setelah 3 kali 40 hari tahapan menjadi manusia yang ditiupkan nyawa kepadanya dan dilahirkan ke dunia.

Kemudian dia berwarna sesuai iklim, hawa udara, letak tanah dan peredaran musimnya sehingga timbullah berbagai macam warna kulit, wajah dan bahasa. Mereka hidup terpisah di berbagai belahan dunia karena mencari tanah yang sesuai, dan mereka terbagi menjadi kelompok yang lebih besar yaitu bangsa yang terpecah menjadi suku yang kemudian terbagi menjadi keluarga.

Kemuliaan sejati di sisi Allah tak lain kemuliaan hati, budi pekerti dan ketaatan kepada-Nya. Maka hal ini juga yang menghapus perasaan manusia yang beranggapan bahwa dirinya lebih dari yang lain. Maka dari itu tidak pantas seseorang membanggakan dirinya ataupun bangsa dengan yang lainnya. ${ }^{16}$ Maka dapat disimpulkan bahwa perbedaan warna kulit, bahasa dan lain sebagainya merupakan penyesuaian dimana ia tinggal, derajat semua manusia adalah sama yang membedakannya adalah kualitas takwa kepada Allah.

${ }^{16}$ Hamka, Tafsir Al-Azhar di Perkaya Dengan Pendekatan Sejarah, Sosiologi, Tasawuf, Ilmu Kalam, Sastra, dan Psikologi, 1 ed., Jilid 7 (Jakarta: Gema Insani, 2015), h. 430-32. 
Fitri Dewi dan Moh Jufriyadi, Kebhinekaan dan Persatuan Perspektif Tafsir Nusantara

\section{Kebhinekaan Agama}

Agama yang ada di Indonesia seperti agama Islam, Katholik, Protestan, Hindu, Budha dan Konghucu merupakan agama resmi warga Indonesia. ${ }^{17}$ Meskipun demikian masyarakat Indonesia masih bisa hidup di tengah keberagaman. ${ }^{18}$ Beberapa kajian menyatakan bahwa agama merupakan kebutuhan mendasar yang sangat dibutuhkan dalam kehidupan manusia. Islam memandang kebutuhan terhadap agama adalah fitrah setiap manusia, karena agama merupakan kebutuhan hidup. ${ }^{19}$ Ayat yang menyatakan adanya keberadaan agama lain yaitu yang berbunyi. ${ }^{20}$

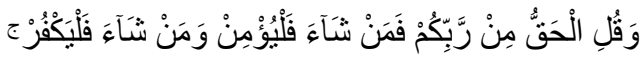

"Dan katakanlah: "Kebenaran itu datangnya dari Tuhanmu; maka barangsiapa yang ingin (beriman) hendaklah ia beriman, dan

${ }^{17}$ Anwar, "Islam dan Kebhinekaaan di Indonesia : Peran Agama dalam Merawat Perbedaan," 2.

${ }^{18}$ Firdaus M Yunus, “Agama dan Pluralisme," Jurnal Ilmiah ISLAM FUTURA Vol. 13, No. 2 (Fenruari) 2014, h. 215.

19 Dewi Murni, "Toleransi dan Kebebasan Beragama dalam Persepektif al-Qur'an,” Jurnal Syahadah Vol. VI, No. 2 (Oktober) 2018, h. 72 .

${ }^{20}$ Fahma Maulida, "Penafsiran Misbāh Mustafā atas Ayat-ayat Kebhinekaan Agama dan Budaya dalam tafsir al-Iklil Fi Ma'āni alTanzill” (Tulung Agung, (Institut Agama Islam Negeri, 2019), h. 103. 
Volume 3, Number 1, Januari - Juli 2021

barangsiapa yang ingin (kafir) biarlah ia kafir"......... (QS. AlKahfị 18̣: 29)

Allah mengutus rasul-Nya untuk menyampaikan wahyu ilahi kepada umat manusia. Siapa yang mau beriman maka berimanlah, dan siapa yang menolak maka biarkanlah ia kafir. Karena diantara mereka yang merugi merupakan sebab dari perbuatan mereka sendiri. ${ }^{21}$ Padahal mereka diberi akal untuk berfikir. Mereka yang menolak pada kebenaran akan berakhir pada kesengsaraan. ${ }^{22}$

Fungsi Agama

Agama memilki fungsi tersendiri bagi umat manusia, hal tersebut dapat kita lihat dari segi sosial dan personal. ${ }^{23}$ Dintara fungsi agama yaitu:

${ }^{21}$ M. Quraish Shihab, Tafsir al-Mishbāh Pesan, Kesan dan Keserasian al-Qur'an, Jilid 8 (Jakarta: Lentera Hati, 2002), h. 52.

${ }^{22}$ Hamka, Tafsir Al-Azhar di Perkaya Dengan Pendekatan Sejarah, Sosiologi, Tasawuf, Ilmu Kalam, Sastra, dan Psikologi, 1 ed., Jilid 5 (Jakarta: Gema Insani, 2015), h. 353-354.

${ }^{23}$ Muchlis M. Hanafi, ed., Tafsir al-Qur'an Tematik Hubungan antar Umat Beragama, Cet. 1, Jilid 3 (Jakarta: Departemen Agama RI, Badan Litbang dan Diklat, Lajnah Pentashihan Mushaf al-Qur'an, 2008), h. 13 . 
Fitri Dewi dan Moh Jufriyadi, Kebhinekaan dan Persatuan Perspektif Tafsir Nusantara

1. Pembimbing dan Pendidik

Tidak dapat dipungkiri bahwa agama memberikan pendidikan dan pengajaran melalui para rasul-Nya, Sebagaimana firman-Nya (QS. Al-Baqarah 2: 151)

yang menjelaskan bahwa Allah telah mengutus seorang Rasul kepada umat manusia untuk mengajarkan al-kitab (alQur'an) dan hikmah (rahasia hidup dalam sabda Rasulullah). Dalam mengajarkan sesuatu membutuhkan kesungguhan. ${ }^{24}$ Dan masih banyak persoalan besar yang tidak diketahui bisa diketahui melalui wahyu ilahi. ${ }^{25}$

2. Penyelamat

Dalam kehidupan penuh dengan misteri yang tidak diketahui dan tidak mampu untuk kita pecahkan dengan akal pikiran, sehingga datanglah berbagai harapan agar Allah datang dan membantu melalui zikir dan doa. Sebagaimana firman-Nya:

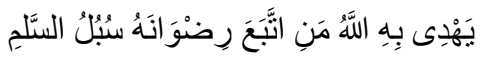

${ }^{24}$ M. Quraish Shihab, Tafsir al-Mishbāh Pesan, Kesan dan Keserasian al-Qur'an, Jilid 1 (Jakarta: Lentera Hati, 2002), h 337-339.

${ }^{25}$ Hamka, Tafsir al-Azhar di Perkaya Dengan Pendekatan Sejarah, Sosiologi, Tasawuf, Ilmu Kalam, Sastra, dan Psikologi, 1 ed., Jilid 1 (Jakarta: Gema Insani, 2015), h. 283. 
Volume 3, Number 1, Januari - Juli 2021

e-ISSN 2716-4241

ISSN 2723-2344

"Dengan kitab itulah Allah menunjuki orang-orang yang mengikuti keridhaan-Nya ke jalan keselamatan, ........ (QS. Al-Maidah 5़: 16)

Menjelaskan bahwa dengan cahaya dan kitab suci tersebut menunjuki jalan bagi orang yang berusaha mencapai jalan yang diridhoi Allah, sehingga ditunjukilah berbagai macam jalan keselamatan. dan terbebas dari bencana dunia maupun akhirat. ${ }^{26}$ Manusia akan mendapatkan 3 tingkat kebahagiaan: pertama, meraih kedamaiaan. Kedua, keluar dari kegelapan. Ketiga, jalan yang lurus. ${ }^{27}$

3. Pengingat dan Kabar Gembira

Sebagaimana firman-Nya (QS. Al-an’am. 6: 48) yang menjelaskan bahwa Allah telah mengut us para rasul-Nya untuk menyampaikan kabar gembira untuk umat yang patuh serta pengingat untuk yang ingkar. Allah memerintahkan untuk mengadakan perbaikan dalam hal yang positif. ${ }^{28}$

26 M. Quraish Shihab, Tafsir al-Mishbāh Pesan, Kesan dan Keserasian al-Qur'an, Cet. IV., Jilid 3 (jakarta: Lentera Hati, 2005), h. 54.

${ }^{27}$ hamka, Tafsir al-Azhar di Perkaya dengan Pendekatan Sejarah, Sosiologi, Tasawuf, Ilmu Kalam, Sastra, dan Psikologi, Cet. 1., Jilid 2 (jakarta: gema Insani, 2015), h. 644-645.

28 M. Quraish Shihab, Tafsir al-Mishbāh Pesan, Kesan dan Keserasian al-Qur'an, Cet. III., Jilid 4 (Jakarta: Gema Insani, 2005), h. 106-107. 
Fitri Dewi dan Moh Jufriyadi, Kebhinekaan dan Persatuan Perspektif Tafsir Nusantara

Menjelasakan tentang keadaan orang kafir dan orang beriman saat menghadapi maut, baik dalam keadaan terbunuh ataupun tertidur, namun lebih ditekankan dalam keadaan beriman ataupun kafir saat menghadapi maut. Orang beriman tidak pernah risau tentang setelah maut karena mereka tidak pernah meninggalkan iman dan selalu meningkatkan mutu keimanannya. ${ }^{29}$

4. Persaudaraan

Berkelompok berdasarkan identitas contohnya dapat berbentuk kesamaan bahasa, etnis, ras, kelas dan lain sebagainya. perbedaan digunakan untuk saling melengkapi agar lebih kuat. ${ }^{30}$

\section{Pengontrol Sosial}

Setiap prilaku manusia dikontrol oleh peraturan agama sebagaimana firman-Nya (QS. 'Ali 'Imrān . 3: 104) ayat tersebut menjelaskan bahwa setiap umat manusia perlu untuk diberi peringatan dan keteladanan itulah poin dari dalwah islamiyah. Dimana ayat tersebut memerintahkan umat manusia untuk berdakwah sesuai dengan kemampuannya.

29 Tafsir al-Azhar di Perkaya dengan Pendekatan Sejarah, Sosiologi, Tasawuf, Ilmu Kalam, Sastra, dan Psikologi, Cet. I., Jilid 3 (Jakarta: Gema Insani, 2015), h. 152.

${ }^{30}$ M. Hanafi, Tafsir al-Qur'an tematik, h. 18. 
Yaitu mengajak berbuat baik dan melarang untuk berbuat keburukan. ${ }^{31}$

Ada dua jenis dalam berdakwah pertama bersifat mengajak orang lain agar dapat memahami hikmah ajaran agama Islam serta menangkis yang tidak benar terhadap Islam. Kedua bersifat khusus yaitu berdakwah terhadap keluarga sendiri. $^{32}$

6. Penyadaran Peran Sosial

Manusia tidak dapat hidup sendiri karena makhluk sosial contohnya: berzakat, tidak mengambil harta anak yatim ${ }^{33}$ dan lain sebagainya sebagaimana firman-Nya (QS. Az-zariyat 51: 19)

Ayat tersebut menjelaskan tentang harta yang dimiliki untuk dizakatkan kepada yang layak menerimanya jika telah memenuhi syarat. Karena pada realitanya banyak orang yang mau meminta zakat karena beranggapan bahwa dirinya pantas untuk mendapatkannya, namun ada juga orang yang pantas

31 M. Quraish Shihab, Tafsir al-Mishbāh Pesan, Kesan dan Keserasian al-Qur'an, Jilid 2 (Jakarta: Lentera Hati, 2002), h. 176-175.

${ }^{32}$ Hamka, Tafsir al-Azhar di Perkaya dengan Pendekatan Sejarah, Sosiologi, Tasawuf, Ilmu Kalam, Sastra, dan Psikologi, h. 2425.

${ }^{33}$ M. Hanafi, Tafsir al-Qur'an tematik, h. 22. 
Fitri Dewi dan Moh Jufriyadi, Kebhinekaan dan Persatuan Perspektif Tafsir Nusantara

untuk mendapatkannya namun ia malu untuk memintanya karena masih menjaga harga dirinya.

\section{Kebhinekaan Sunnahtullah}

Keberagaman yang terjadi di muka bumi, baik dari aspek budaya, suku bangsa, warna kulit, agama dan lain sebagainya adalah sunnahtullah. Keagamaan yang ada dan berkembang di Indonesia berasal dari luar Indonesia. Contohnya agama Islam yang dibawa pedagang ke Indonesia dimana penduduknya sudah menganut agama Budha, namun mereka mengenalkan agama Islam tanpa kekerasan sehingga masyarakat tertarik untuk memeluk agama Islam dengan melalui berbagai media, seni ataupun budaya setempat. Namun agama berkembang dengan damai. ${ }^{34}$ Dapat dikatakan bahwa bumi ini plural dari aspek suku, agama, bahasa dan lain sebagainya. Dimana hal tersebut merupakan rahmat yang tidak dapat dihindari. ${ }^{35}$ Sebagaimana firman-Nya yang menyatakan bahwa hal tersebut merupakan sunnahtullah.

${ }^{34}$ Dewa Agung Gede Agung, "Keragaman Keberagamaan (Sebuah Kodrati Kehidupan Berbangsa dan Bernegara Berdasarkan Pancasila)," Jurnal Sejarah dan Budaya Vol.11, No. 2 (Desember) 2017, h. 152 .

${ }^{35}$ Agung Gede Agung, h. 157. 


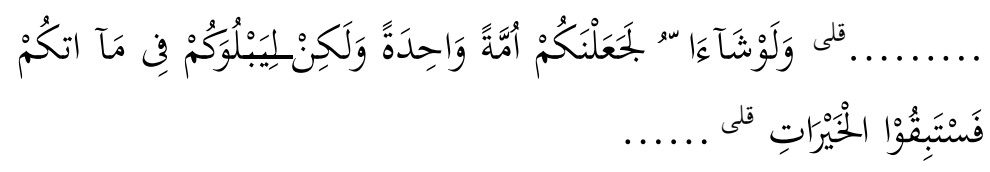

“.........Kalau Allah menghendaki, niscaya kamu dijalanNya satu umat (saja), akan tetapi Allah hendak menguji kamu terhadap karunia yang telah diberikan-Nya kepadamu, maka berlomba-lombalah berbuat kebajikan......”. (QS. Al-Maidah. 5: $48)^{36}$

Ayat tersebut menjelaskan keanekaragaman yang ada bukan karena Allah tidak berkuasa untuk menyatukannya. Akan tetapi Allah menguji umat manusia seberapa jauh dapat menggunakan akalnya. Karena setiap manusia dapat berfikir dan berijtihad dengan dasar menuju kebaikan, yang pasti akan ada perbedaan pendapat. Dimana manusia memiliki pikiran dan kepribadian. ${ }^{37}$ Akan tetapi asal dasar itu menuju kebaikan dan takwa kepada Allah maka lanjutkanlah karena tujuannya sama.

Ayat tersebut bukan digunakan untuk menafikan kehendak Allah menjadikan manusia satu, dalam arti satu keturunan dan asal

\footnotetext{
${ }^{36}$ Irwan Purwanto dkk., al-Qur'an Tiga Bahasa, 10 ed. (Jakarta: al-Huda, 2012), h. 206.

37 Hamka, Tafsir al-Azhar di Perkaya dengan Pendekatan Sejarah, Sosiologi, Tasawuf, Ilmu Kalam, Sastra, dan Psikologi, h. 710-711.
} 
Fitri Dewi dan Moh Jufriyadi, Kebhinekaan dan Persatuan Perspektif Tafsir Nusantara

usul. Karena manusia dalam hal kesatuan asal usul adalah satu. Yang demikian itu merupakan kehendak Allah. ${ }^{38}$

\section{Kebhinekaan Budaya}

Kebudayaan merupakan suatu kebiasaan pola hidup manusia yang dihasilkan oleh manusia itu sendiri. ${ }^{39}$ Yang merupakan warisan dari nenek moyang mereka serta diterapkan sampai saat ini oleh masyarakat. Budaya tersebut memberi ciri khas bagi suatu bangsa. Sedangkan ajaran-ajaran Islam yang sangat kental dengan ajaran dasar merupakan tradisi besar Islam, seperti keimanan serta syariah yang tumbuh menjadi inspirasi pola tindak umat Islam. $^{40}$ Kemudian ayat yang membahas tentang kebhinekaan budaya yaitu QS. Ar-Rūm 30̣: 22

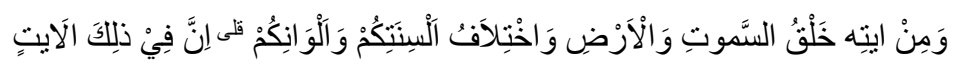

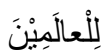

${ }^{38}$ Quraish Shihab, Tafsir al-Mishbāh Pesan, Kesan dan Keserasian alQur'an, h. 116.

${ }^{39}$ Laode Monto Bauto, "Perspektif Agama dan Kebudayaan dalam Kehidupan Masyarakat Indonesia (Suatu Tinjauan Sosiologi Agama)," JPIS, Jurnal Pendidikan Ilmu Sosial Vol. 23, No. 2 (Desember) 2014, h. 12.

${ }^{40}$ Monto Bauto, h. 13-14. 
"Dan diantara tanda-tanda (kebesaran)-Nya ialah penciptaan langit dan bumi, perbedaan bahasamu, dan warna kulitmu. Sungguh, pada yang demikian itu benar-benar terdapat tandatanda bagi orang-orang yang mengetahui”. (QS. Ar-Rūm 30̣: $22)^{41}$

Ayat di atas menjelaskan tentang kekuasaan Allah yang menciptakan sesuatu dengan berpasang-pasangan. Misalnya lakilaki dengan perempuan, bumi dengan langit, penyakit dengan obat dan masih banyak lagi. Akan tetapi sesuatu yang berpasangpasangan pastinya berlainan. Misalnya suara manusia tidaklah sama dengan yang lain.

Ayat tersebut menjelaskan tentang perbedaan lidah dalam diri manusia. Hal tersebut terjadi disebabkan perbedaan tempat tinggal di bumi. Sama halnya dengan perbedaan warna kulit yang disebabkan oleh cahaya matahari di belahan dunia yang berbeda. antara manusia yang satu dengan lainnya berbeda, padahal mereka semua terlahir dari asal usul yang sama.

Kata (السنتكم) yaitu jamak dari (لسان) yang dapat diartikan dengan lidah. Akan tetapi, digunakan dalam arti "bahasa atau

${ }^{41}$ Laksana, Arramly, dan Raup, Yasmina al-Qur'an Terjemahan dan Tajwid, h. 406. 
Fitri Dewi dan Moh Jufriyadi, Kebhinekaan dan Persatuan Perspektif Tafsir Nusantara

suara". Namun bukan berarti tidak ada rahasia di balik sesuatu yang sudah tampak. Karena masih banyak rahasia yang belum terungkap. Seperti halnya perbedaan warna kulit, suara atau pun bahasa, masih menjadi pertanyaan bagi banyak orang. ${ }^{42}$

Meskipun manusia hidup di bawah atap yang sama. Namun, mereka memiliki bahasa yang bervariasi. Misalnya bahasa Inggris, Prancis, Rusia, Spanyol, Itali dan lain sebagainya. Sedangkan di Indonesia yang memiliki bahasa daerah yang tidak kurang dari tiga ratus bahasa daerah. Masih memiliki bahasa persatuan bangsa yang dapat mempersatukan pulau-pulau yang ada di Indonesia.

Dari perbedaan bahasa dan variasi warna kulit seperti warna kulit hitam, sawo matang, putih, kuning serta merah yang terdapat pada bangsa India di Amerika. Kemudian yang tergolong perbedaan kulit yaitu perbedaan warna wajah. Dari sekian banyak penduduk bumi tidak memiliki bentuk rupa yang sama. Allah menganugerahkan kepribadian yang berbeda-beda, baik dari aspek bentuk kepala, hidung, mata, sidik jari, kepala, raut muka semuanya tidaklah sama. Sudah beribu-ribu manusia yang hidup

${ }^{42}$ M. Quraish Shihab, Tafsir al-Mishbāh Pesan, Kesan dan Keserasian al-Qur'an, Jilid 11 (Jakarta: Lentera Hati, 2002), h. 37-38. 
di muka bumi namun tidak sama. Maka Allah merupakan zat yang sangat kaya dengan rupa dan bentuk yang demikian. ${ }^{43}$

Maka dapat disimpulkan bahwa kebhinekaan bahasa, warna kulit dan lain sebagainya dipengaruhi oleh keadaan tempat ia tinggal hal tersebut menunjukkan kekuasaan-Nya dan kekayaan rupa yang Allah miliki.

\section{HAKIKAT PERSATUAN}

Persatuan adalah kesataun yang pada dasarnya setiap manusia adalah satu, sebab pada realitanya setiap manusia tidak sama dengan yang lainnya. Namun melalui persatuan bukan berarti melebur menjadi satu, akan tetapi keanekaragaman tetap terpelihara dan saling melengkapi agar menjadi sesuatu yang positif. ${ }^{44}$ Sebagaimana firman-Nya:

${ }^{43}$ Hamka, Tafsir Al-Azhar di Perkaya Dengan Pendekatan Sejarah, Sosiologi, Tasawuf, Ilmu Kalam, Sastra, dan Psikologi, h. 5253.

${ }^{44}$ Endang Pristiawi, Sonia Haira Rahma, dan Laila Munada, "Perumpamaan Kesatuan dan Persatuan dalam al-Qur'an (Analisis Q.S Ibrahim: 24 al-Mu'minun: 52 'A Tata Negara)," Journal of Islamic Law and Studies Vol.1, No.1 (Juni) 2017, h. 15. 
Fitri Dewi dan Moh Jufriyadi, Kebhinekaan dan Persatuan Perspektif Tafsir Nusantara

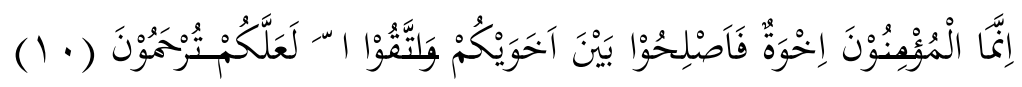

Artinya:Sesungguhnya orang-orang mukmin itu bersaudara, karena itu damaikanlah antara kedua saudaramu (yang berselisih) dan bertakwalah kepada Allah agar kamu mendapat rahmat."(QS. Al-Hujurāt: 10) $)^{45}$

Asbabun nuzul ayat diriwayatkan oleh Qatādah bahwa ayat berkaitan dengan kejadian dua orang yang merupakan sahabat Ansar yang berselisih mengenai perkara hak milik. Satu diantara mereka berkata bahwa ia akan merebut secara paksa haknya dari orang lain. Sebab pengikutnya banyak sehingga ia berani mengancam, sementara yang satu mengajaknya agar minta keputusan dari Nabi Muhammad Saw, Namun ia menolak sehingga perkara diantara mereka memunculkan perkelahian, walaupun tidak menggunakan senjata. ${ }^{46}$

Ayat tersebut menjelaskan bahwa persaudaraan merupakan pokok kehidupan orang beriman. Seseorang tidak mungkin bermusuhan jika telah tumbuh iman dalam hatinya. Jika terjadi

${ }^{45}$ Laksana, Arramly, dan Raup, Yasmina al-Qur'an Terjemahan dan Tajwid, h. 516.

${ }^{46}$ Ahsin Sakho Muhammad dkk., al-Qur'an dan Tafsir (Edisi yang Disempurnakan), jilid 9 (Jakarta: Widya cahaya, 2011), h. 419. 
perselisihan tentunya disebabkan oleh faktor lain misalnya salah paham.

Ayat tersebut mengingatkan agar mendamaikan kedua saudara yang beselisih serta menjelaskan cara untuk mendamaikannya yaitu dengan bertakwa kepada Allah. Maksudanya bahwa dalam mempersatukan mereka tidak ada niat lain selain untuk mendapat ridho Allah. Niat yang suci berlandaskan iman dan ketakwaan. Orang yang berusaha untuk mendamaikan mereka besar harapannya untuk mendapatkan rahmat Allah. ${ }^{47}$

Kemudiaan kata (إِخْوَة) yaitu jamak dari $\left(\dot{\gamma}^{\prime}\right)$ yang sering diartikan "saudara atau sahabat" awalnya diartikan "yang sama" yaitu persamaan garis keturunan yang menyebabkan persaudaraan. Kata (إخوان) bentuk tunggal dari kata tersebut biasanya menunjuk yang bukan sekandung. Sedangkan (إخْوَة) diulang 7 kali dalam al-Qur'an dan semuanya digunakan untuk menunjukkan persaudaraan sekandung. Kecuali ayat di atas mengisyaratkan persaudaraan orang beriman yang dasarnya berganda. Pertama, berdasarkan keimanan. Kedua, berdasarkan

${ }^{47}$ Hamka, Tafsir Al-Azhar di Perkaya Dengan Pendekatan Sejarah, Sosiologi, Tasawuf, Ilmu Kalam, Sastra, dan Psikologi, 1 ed., Jilid 8 (jakarta: Gema Insani, 2015), h. 424. 
Fitri Dewi dan Moh Jufriyadi, Kebhinekaan dan Persatuan Perspektif Tafsir Nusantara

keturunan. Akan tetapi no dua bukan makna secara hakiki, namun tidak ada alasan untuk memutus persaudaraan. Kesatuan dan persatuan baik dalam masyarakat kecil maupun masyarakat besar akan melimpahkan rahmat. Sedangkan perselisihan dapat menimbulkan pertumpahan darah. ${ }^{48}$

Maka dapat disimpulkan bahwa persatuan bagaikan persaudaraan merupakan pokok kehidupan dan tidak akan tumbuh perselisihan jika telah tumbuh iman di hatinya. Mendamaikan saudara yang berselisih akan mendapat rahmat Allah dengan niat mencari ridho Allah, dimana bersatu bagaikan persaudaraan berdasarkan keimanan dan keturunan.

\section{KESIMPULAN}

Dari penelitian ini terdapat persamaan konsep kebhinekaan menurut M. Quraish Shihab dan Hamka yaitu perbedaan warna kulit, bentuk wajah, bahasa dan lain sebagainya Pada dasarnya derajat manusia adalah sama yang membedakannya adalah kualitas takwa. Allah menjadikan manusia berbangsa, bersuku dan berkelompok agar saling mengenal. Maka tidak pantas seseorang membanggakan dirinya, sukunya ataupun bangsanya dari yang

${ }^{48}$ Quraish Shihab, Tafsir al-Mishbāh Pesan, Kesan dan Keserasian al-Qur'an, 247-249. 
lain, sedangkan perbedaan warna kulit, bentuk wajah dan lain sebagainya dipengaruhi tempat dimana ia tinggal. Hal tersebut menunjukkan akan kekayanya yang dimiliki oleh Allah. Sementara kebhinekaan budaya yang diterapkan oleh setiap masyarakat adalah berbeda, namun kebudayaan tersebut dapat memberikan ciri tersendiri bagi masyarakat yang menerapkannya. Kemudian dari sekian banyak agama yang ada tentunya setiap agama memiliki doktrin-doktrin tersendiri yang dibutuhkan dalam kehidupan manusia serta dapat dijadikan pedoman hidup.

Kemudian makna persatuan menurut Hamka dan M. Quraish Shihab yaitu persatuan bagaikan persaudaraan orang beriman yang merupakan pokok kehidupan berdasarkan keimanan dan keturunan, dimana persatuan yang melimpahkan rahmat dalam masyarakat besar ataupun kecil sedangkan perselisihan mampu menimbulkan petumpahan darah.

Meskipun penelitian ini hanya membandingkan dua pemikiran mufassir Nusantara, namun penulis berharap dapat mewakili konsep kebhinekaan dan persatuan. Maka dari itu perlu untuk dilakukan penelitian lebih lanjut tentang kebhinekaan dan persatuan tersebut, akan tetapi bukan hanya dari aspek tafsir namun dari berbagai aspek seperti: sosial, fiqih, hadis, dan lain 
Fitri Dewi dan Moh Jufriyadi, Kebhinekaan dan Persatuan Perspektif Tafsir Nusantara

sebagainya. Agar dapat mengetahui secara mendetail hakikat kebhinekaan dan persatuan.

\section{DAFTAR PUSTAKA}

Agung Gede Agung, Dewa. "Keragaman Keberagamaan (Sebuah Kodrati Kehidupan Berbangsa dan Bernegara Berdasarkan Pancasila)." Jurnal Sejarah dan Budaya Vol 11 No 2 (Desember 2017).

Anwar, Choirul. "Islam dan Kebhinekaaan di Indonesia : Peran Agama dalam Merawat Perbedaan.” Jurnal Pemikiran Islam 'Zawiyah Vol 4, No. 2 (Desember 2018).

Arib, Maqbul. "Dakwah di Tengah Keragaman dan Perbedaan Umat Islam.” Jurnal Dakwah Tabligh 15 (2014).

Hamka. Tafsir Al-Azhar di Perkaya Dengan Pendekatan Sejarah, Sosiologi, Tasawuf, Ilmu Kalam, Sastra, dan Psikologi. 1 ed. Jilid 7. Jakarta: Gema Insani, 2015.

- Tafsir Al-Azhar di Perkaya Dengan Pendekatan Sejarah, Sosiologi, Tasawuf, Ilmu Kalam, Sastra, dan Psikologi. 1 ed. Jilid 5. Jakarta: Gema Insani, 2015.

—. Tafsir Al-Azhar di Perkaya Dengan Pendekatan Sejarah, Sosiologi, Tasawuf, Ilmu Kalam, Sastra, dan Psikologi. 1 ed. Jilid 1. Jakarta: Gema Insani, 2015 
Volume 3, Number 1, Januari - Juli 2021

e-ISSN 2716-4241

ISSN 2723-2344

—. Tafsir Al-Azhar di Perkaya Dengan Pendekatan Sejarah, Sosiologi, Tasawuf, Ilmu Kalam, Sastra, dan Psikologi. Cet. 1. Jilid 2. Jakarta: gema Insani, 2015.

- Tafsir Al-Azhar di Perkaya Dengan Pendekatan Sejarah, Sosiologi, Tasawuf, Ilmu Kalam, Sastra, dan Psikologi. Cet. I. Jilid 3. Jakarta: Gema Insani, 2015.

- Tafsir Al-Azhar di Perkaya Dengan Pendekatan Sejarah, Sosiologi, Tasawuf, Ilmu Kalam, Sastra, dan Psikologi. 1 ed. Jilid 8. Jakarta: Gema Insani, 2015.

Laksana, Indra, Syamsu Arramly, dan Abdul Raup. Yasmina alQur'an Terjemahan dan Tajwid. 1 ed. Bandung: PT Sygma Examedia Arkanleema, 2014.

M. Hanafi, Muchlis, ed. Tafsir al-Qur'an Tematik Hubungan antar Umat Beragama. Cet. 1. Jilid 3. Jakarta: Departemen Agama RI, Badan Litbang dan Diklat, Lajnah Pentashihan Mushaf al-Qur'an, 2008.

Mahmudi, Jumiati. "Implementasi Ta'aruf dalam Surat AlHujurat Ayat 13 Persepektif Mufassir Klasik dan Modern (Studi Komparatif Tafsir Al-Qurtubi dan Tafsir Al-Munir)." Institut Dirosat Islamiyah Al-Amien (IDIA), 2018.

Maulida, Fahma. "Penafsiran Misbāh Mustafā atas Ayat-ayat Kebhinekaan Agama dan Budaya dalam tafsir al-Iklil Fi Ma'āni al-Tanzill." (Institut Agama Islam Negeri, 2019. 
Fitri Dewi dan Moh Jufriyadi, Kebhinekaan dan Persatuan Perspektif Tafsir Nusantara

Monto Bauto, Laode. "Perspektif Agama dan Kebudayaan dalam Kehidupan Masyarakat Indonesia (Suatu Tinjauan Sosiologi Agama)." JPIS, Jurnal Pendidikan Ilmu Sosial vol 23 no 2 (Desember 2014).

Mubaidillah. "Tafsir Al-Lubab Karya M. Quraish Shihab (Kajian Metodologi Tafsir Kontemporer).” Nur El-Islam Vol. 3 no 1 (April 2016).

Murni, Dewi. "Toleransi dan Kebebasan Beragama dalam Persepektif al-Qur'an." Jurnal Syahadah Vol VI No 2 (Oktober 2018).

Nyoman Pursika, I. "Kajian Analitik Terhadap Semboyan 'Bhineka Tunggal Ika." Jurnal Pendidikan dan Pengajaran Jilid 42, Nomor 1, (April 2009).

Pristiawi, Endang, Sonia Haira Rahma, dan Laila Munada. "Perumpamaan Kesatuan dan Persatuan dalam al-Qur'an (Analisis Q.S Ibrahim: 24 al-Mu'minun: 52 'Ali 'Imran:103 dalam Bingkai Hukum Tata Negara).” Journal of Islamic Law and Studies 1 (Juni 2017).

Purwanto, Irwan, Arifin, Suhud Raksa, dan Mursali. al-Qur'an Tiga Bahasa. 10 ed. Jakarta: al-Huda, 2012.

Quraish Shihab, M. Tafsir Al-Mishbāh Pesan, Kesan dan Keserasian al-Qur'an. Jilid 13. Jakarta: Lentera Hati, 2002. - Tafsir Al-Mishbāh Pesan, Kesan dan Keserasian alQur'an. Jilid 8. Jakarta: Lentera Hati, 2002. 
Volume 3, Number 1, Januari - Juli 2021

—. Tafsir Al-Mishbāh Pesan, Kesan dan Keserasian alQur'an. Jilid 1. Jakarta: Lentera Hati, 2002.

—. Tafsir Al-Mishbāh Pesan, Kesan dan Keserasian alQur'an. Jilid 2. Jakarta: Lentera Hati, 2002.

—. Tafsir Al-Mishbāh Pesan, Kesan dan Keserasian alQur'an. Jilid 11. Jakarta: Lentera Hati, 2002.

- Tafsir Al-Mishbāh Pesan, Kesan dan Keserasian alQur'an. Cet. IV. Jilid 3. Jakarta: Lentera Hati, 2005.

- Tafsir Al-Mishbāh Pesan, Kesan dan Keserasian alQur'an. Cet. III. Jilid 4. Jakarta: Gema Insani, 2005.

Sa'dan, Masthuriyah. "Toleransi : Media Komunikasi Umat Beragama." Lembaga Penelitian dan Pengabdian Kepada Masyarakat 7 (2015).

Sakho Muhammad, Ahsin, Atho Mudzhar, Fhadal AE. Bafadal, Ali Mustafa Yaqub, Muhammad Shohib, dan Rif' at Syauqi Nawawi. al-Qur'an dan Tafsir (Edisi yang Disempurnakan). jilid 9. Jakarta: Widya cahaya, 2011.

Setiawan, Yuliyanto Budi. "Kontestasi Isu Kebhinekaan dalam Media Sosial." Preprint. INA-Rxiv, 3 Januari 2018. https://doi.org/10.31227/osf.io/am2hk.

Sugiono. Metode Penelitian Kombinasi (Mixed Methods). Bandung: Alfabeta, 2017. 
Fitri Dewi dan Moh Jufriyadi, Kebhinekaan dan Persatuan Perspektif Tafsir Nusantara

Sumisih, Susi. "Konsep Bhineka tunggal Ika dalam Perspektif Tafsir al-Azhar dan Kontribusinya Bagi Negara Kesatuan Republik Indonesia." Universitas Islam Negeri Raden Intan, 2019.

Syafii Maarif, Ahmad, Lukman Hakim Saifuddin, M. Amin Abdullah, Syamsul Anwar, Azyumardi Azra, Hamim Ilyas, Zakiyuddin Baidhawy, dkk. "Fikih Kebinekaan," Cet. I. Jakarta: Mizan, 2015.

Yunus, Firdaus M. “Agama dan Pluralisme.” Jurnal Ilmiah ISLAM FUTURA vol 13 no 2 (Fenruari 2014). 